\title{
Correction to: Non-native regal demoiselle, Neopomacentrus cyanomos, presence, abundance, and habitat factors in the North-Central Gulf of Mexico
}

\author{
Joseph H. Tarnecki $(\mathbb{D} \cdot$ Steven B. Garner (D) - William F. Patterson III $($ )
}

Published online: 30 March 2021

(C) Springer Nature Switzerland AG 2021

\section{Correction to: Biol Invasions}

https://doi.org/10.1007/s10530-020-02424-0

Unfortunately, the original publication of the article has been published with an error in third author's name. The correct author name is given in this correction.
The original article has been corrected.

Publisher's Note Springer Nature remains neutral with regard to jurisdictional claims in published maps and institutional affiliations.

e-mail: jtarnecki@ufl.edu 